\title{
Top Management Team Heterogeneity, Corporate Social Responsibility Disclosure and Financial Performance
}

\author{
Pinky Gupta \\ School of Business Administration, South China University of Technology, Guangzhou, China \\ Email: guppinky@hotmail.com
}

How to cite this paper: Gupta, P. (2019) Top Management Team Heterogeneity, Corporate Social Responsibility Disclosure and Financial Performance. American Journal of Industrial and Business Management, 9 , 1076-1093.

https://doi.org/10.4236/ajibm.2019.94074

Received: March 26, 2019

Accepted: April 25, 2019

Published: April 28, 2019

Copyright $\odot 2019$ by author(s) and Scientific Research Publishing Inc. This work is licensed under the Creative Commons Attribution International License (CC BY 4.0).

http://creativecommons.org/licenses/by/4.0/

\begin{abstract}
The purpose of this study is to examine the relationship between top management team (TMT) heterogeneity, corporate social responsibility disclosure (CSRD) and financial performance of banks listed in the Nepal Stock Exchange (NEPSE) by applying the conceptual framework of upper echelon theory. A sample of top 29 banks is studied from 2012 to 2017. The data is collected from their annual reports and websites. The results reveal that TMT heterogeneity and CSRD had a significant positive effect on the bank's financial performance. CSRD plays a mediation role between TMT heterogeneity and financial performance. However, the effect of TMT gender heterogeneity on CSRD is insignificant. This study contributes to our understanding about how TMT heterogeneity affects financial performance through CSRD. This study also gives us new evidence to explore the link between TMT heterogeneity, CSRD and firm financial performance in emerging market.
\end{abstract}

\section{Keywords}

Corporate Social Responsibility Disclosures, Firm Financial Performance, Global Reporting Initiative (GRI) G4 Guidelines, TMT Heterogeneity

\section{Introduction}

Corporate social responsibility has become a well-known issue concerned by scholars, entrepreneurs and government in Nepal. It is considered as one of the important research topics [1]. Not only has this topic received academic attention but it is also becoming a mainstream issue and regarded as the most prevalent topic for many organizations [2]. As Nepal is a developing country, it has started to encourage listed companies to issue CSR reports since 2006, which is 
relatively later than with foreign countries. CSR is relatively a very new concept for a country like Nepal. Nepal is facing a number of issues towards economic development. CSR in Nepal is progressively becoming a priority as it is considered as one of the most important factors to contribute to economic development and nation's growth because it is accepted as an effective concept for corporation to help in solving social problems and strengthening their core business activities [3]. Corporate social responsibility disclosure (CSRD) is a process which provides information about interactions between organizations/firms with regard to environment, employees, society and customer issues [4]. It is also a method of providing financial and non-financial information dealing with the society and environment context [5]. Therefore, the research on CSRD in Nepal is not only of theoretical significance, but also of great practical significance in guiding future development and policy impact.

Top managers hold the core position of strategic leadership, to achieve an enterprise's objectives and play a crucial role in the process of strategic development and implementation [6]. However, the existing literature indicates that research on factors effecting CSR disclosure has mainly concentrated on the effect of corporate characteristics such as company size [7] [8] and type of industry [9]. Few studies have focused on how company's key corporate players affect the organizational level, promoting the establishment of a competitive advantage and improving financial performance. In fact, there is an availability of very limited research in implementation of CSR practice and how the heterogeneity of TMT influences the level of CSR disclosures in banks directly. There are few empirical papers that study how the characteristics of TMT affect corporate social responsibility and mostly they have focused on the relationship between TMT and corporate social responsibility from a single background, lacking the overall study of heterogeneity. It is even rarer in context of developing countries like Nepal.

According to upper echelon theory, CSR is firmly related to TMT characteristics. TMT characteristics (e.g., age, gender, tenure, and educational level) reflect managers' cognitive base and values that ultimately have an effect on business direction as a result of strategic choices [10]. Based on the argument of upper echelon theory, researchers have shown in several studies that strategic CSR is the product of TMT's decisions and discretion [11] [12] [13]. Heterogeneity in TMTs will debate and believes that they are less likely to come to consensus about strategic responses and reasons of poor performance compared with homogenous TMTs [14]. Admittedly, to a large extent, heterogeneous team boosts creativity, innovation and quality strategic choices and could create superior competitiveness [15]. In addition, the top managers (based on effective characteristics mechanisms) is responsible for establishing the appropriate standard of operating objectives, strategies, control mechanism and effective service delivery of the organization [12]. Therefore, the nature of TMT heterogeneity regulates the effectiveness of the performance of the top managers, especially in discharging the CSR activities. 
Because of the rising interest and importance of CSR in today's corporate landscape [2] and due to the evidence that shows the top management team shapes the firm's CSR strategy [16], The purpose of this study is to examine the relationship between TMT heterogeneity, corporate social responsibility disclosure and financial performance as well as to find the current status and performance of CSR of the banks listed in Nepal stock exchange on the basis of CSR disclosure (i.e., economic + social + environmental disclosures) within financial sector. Overall, the aim is to understand the effect of TMT heterogeneity on the "black box" mechanism of financial performance from the angle of corporate social responsibility disclosures. To achieve this objective, three frequently cited representative upper echelon attributes are selected (i.e. age, gender and education level heterogeneity). This study is expected not only to contribute to the upper echelon literature by expanding the area of research into the banking sector but also to provide managerial implications for the banking stakeholders. Moreover, it also explores the trend of CSR disclosure in financial sector. The descriptive analysis exposes that irrespective to sector, the overall trend to disclose CSR activities in listed banks of Nepal is on increasing side from year to year.

This study makes numerous contributions to the existing body of knowledge on the association between TMT heterogeneity, CSR disclosure and financial performance of the top 29 listed companies from the Nepal. This is the first study that would examine the association between TMT heterogeneity, CSR disclosure and financial performance of the top 29 listed companies from the Nepal. Finally, the outcome of this study can contribute to the literature of CSR from the perspective of Nepal listed companies. The consequence of this research can help to bring new perspectives for stakeholders in the practice. If there is an association between TMT heterogeneity, CSR disclosure and financial performance the following groups have benefits. Board of directors and Executives can use the information to make better strategic decision. In practice, the study of TMT heterogeneity will be beneficial for the construction of the top management team and the optimization of the top management structure. According to the relationship between TMT heterogeneity and the strategy of the enterprise, the board of directors can employ the top managers with certain heterogeneity or further train them properly according to the strategic needs for the development of the enterprise. This is conducive for promoting enterprises to standardize their own behavior, better disclosure of relevant information, enhance the competitiveness of enterprises, and ultimately promote the sustainable development of enterprises. However, the present research focuses on identifying the relationship between TMT heterogeneity, CSR disclosure and the financial performance of listed companies in Nepal. This was a difficult task, because there was no mandatory evidence of whether CSR has been implemented in Nepal; therefore, the inherent limitation of the present CSR study was the measurement of CSR actions. In order to overcome this, evidence of CSR was collected through a Global Reporting Initiative (GRI) G4 guidelines, with the result that many com- 
panies in Nepal have implemented CSR which has been disclosed in their annual reports.

The paper is divided into six sections; section two provides an overview of literature and hypothesis development. Section three of the study describes methodology used for examining the relationship between TMT heterogeneity, CSRD and financial performance. Section four describes the variable and their measurement. In section five the empirical results and discussions are presented. Finally, section six provides the conclusion, implication and recommendations for future research.

\section{Literature Review}

Enterprise is not only an independent economic organization, but also a carrier for the survival and development of human society. With the rapid development and expansion of science and technology, especially the high development of information communication technology, CSRD is also a driving force and has become emergence factor for an enterprises' success. The key to gaining competitive advantage is not only to establish a good corporate image, but also to help enterprises create new competitiveness. The rising interest in CSR has also accounted for a growing demand for different firms to transparently measure, report and continuously improve their economic social and environmental performance [17]. Several studies [18] [19] found that, a sound CSRD through Top executives help in improving firm performance, access capital, increase in sale, lower operating cost, and increase in productivity and quality. In [20] they that CSRD can alleviate the information asymmetry between managers and stakeholders, and make stakeholders to respond more actively. Top manager characteristics reflect individual values and beliefs and impact the perception of events in the social context [6], they can also be important factors in which managers choose to fulfill an organization's moral requirements and social responsibilities behavior. Similar opinions were presented by [21] who studied the relationships between top manager attitudes and corporate social responsiveness.

Heterogeneous team refers to the differences in demographic characteristics and key cognitive aspects, values, and experiences among team members. By contrast, homogenous TMTs refer to similarities among team members in the characters mentioned above [11]. Based on the upper echelons literature, in paper [22] heterogeneous top management teams can better handle the simultaneous and conflicting demands and needs of refocusing the organization strategically and improving firm performance efficiently. CEO has a significant impact on strategic decisions making on CSR and information disclosure [23]. Some researchers show that benefits at strategic level are positively related to heterogeneous top management team [24]. The presence of the TMT demographic heterogeneity is expected to increase firm performance [6]. Therefore, the heterogeneous TMT could make high-quality decisions and obtain a greater capability to meet the needs of various stakeholders, and tend to assume social responsibility. 
The legitimacy theory (LT) is considered as most thriving to explain voluntary disclosure because most of the prior researchers appealed that legitimacy theory is the main driver for organization to disclose their CSR practice information in their annual reports [25] [26]. From an upper-echelon theoretical perspective, heterogeneous TMT is considered as a critical resource for the success of organization because of the significant influence it has on the firm's strategic choices and decisions and their implementation [6]. Figure 1 shows the research framework for the study.

\section{Hypothesis Development}

1) Top Management Team Characteristics and Corporate Social Responsibility Disclosure

Specifically, CSR is also viewed as one of the strategic choices and the product of TMT's decisions and discretion [11] [27]. Hence, this paper asserts that TMT heterogeneity is likely to influence the firm's strategic choices and decision, and further examines its impact on CSR strategic choice. Most of these studies point out that the key success factors for adapting CSR activities are top executives strategic decision and leadership [11]. Therefore, the top executives play an important role in determining the content and the level of CSRD [28]. More heterogeneous team holds a larger social and knowledge network while generating ideas [29]. Organization score is higher on CSR when they have democratic rather than republican founders, CEOs, and directors [30]. TMT heterogeneity mean difference in opinions which would lead the team to discuss and analyse the opportunities and threats that exist in the external environment, and can obtain information and solution from different sources for the advantages and disadvantages of different alternatives [6]. Thus, we expect heterogeneous team to be more aware of firm environment and have a greater sense of responsibility to society.

\section{Age heterogeneity}

Age, as an important demographic characteristic, has a great impact on the thinking pattern, management means and decision-making process of top managers. Different age groups signify different environmental events, attitudes, beliefs and values which further reflect the moral development level and risk preference

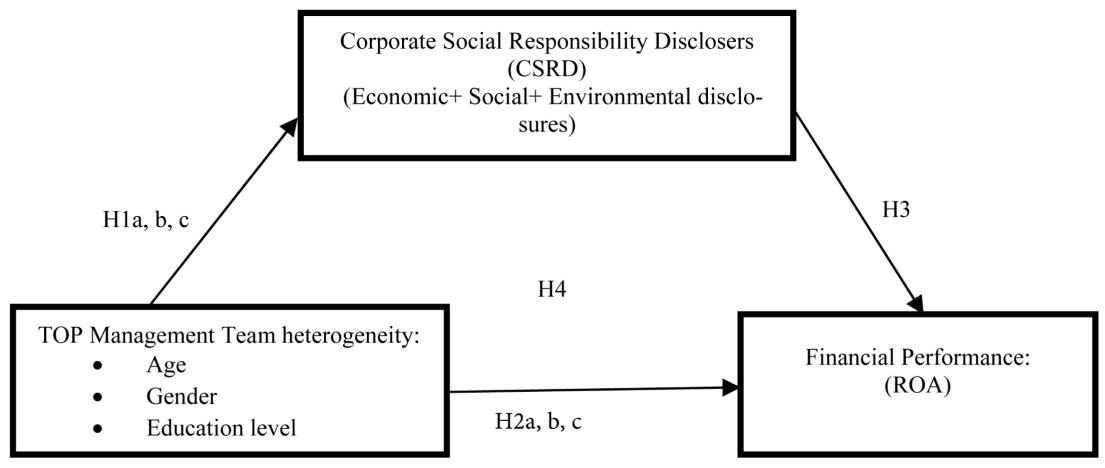

Figure 1. Research framework for the study. 
of different individuals to a certain extent. In paper [31] they studied a special type of corporate social responsibility, and examined how different firms deal with sudden environmental crises. The results show that age heterogeneity contributes to beneficial conflicts because it can discuss a large number of alternative solutions than age homogenous. Therefore, different management strategies are put forward, for example, the age heterogeneity of top management team is considered as an important demographic characteristic that impacts the strategic decision-making of enterprises [29]. It is generally believed that the higher the heterogeneity of the top management team, the more attention companies will pay to all aspects of social responsibility.

\section{Gender heterogeneity}

Gender heterogeneity is an important issue faced by modern business firms. Presence of women as directors in top management positions has been linked to various performance outcomes and therefore there is constant pressure from the global perspective on improving the gender balance in top management positions. For example, females in top management position are more focused and pay higher attention towards social responsibility as compared to their male counterparts [32]. In [33] they analyzed and studied the company data of Standard \& Poor's, and found that male directors and female directors did not share the same concerns. The male executives pay more attention to economic performance, while the female executives showed more interest in social responsibility. The Presence of female members in the board of directors has a positive impact on corporate social performance (CSP) in fortune 500 companies [34]. Proportion of females is often used as a proxy of gender heterogeneity [35].

\section{Education level heterogeneity}

Heterogeneity in education level can reflect top manager's capabilities of gathering and processing innovative and complex information. Similarly, heterogeneity in education level enhances problem solving and decision-making process in dynamic business environments. In [29] they found that heterogeneity in education level of top managers and positively associated with change in the corporate strategy. According to [36], well-educated executives' pay more attention to business ethics and corporate social responsibility than less educated executives. Therefore, we can believe that the higher the heterogeneity of education level is, the more diverse and comprehensive the perspectives of top executives are, the more comprehensive and profound the team's overall understanding of information will be, the more inclined it will be towards change and innovation, and therefore more receptive it will be to new social perspectives, such as the corporate social responsibility.

The evidences and outcomes discussed above so far indicate heterogeneity in age, gender and education level are more likely to have positive influence on social responsibility. Therefore, the following hypotheses are proposed:

H1: The TMT heterogeneity will have positive influence on corporate social responsibility disclosures.

H1a: Age heterogeneity in TMT will have positive influence on the CSR dis- 
closures.

H1b: Gender heterogeneity in TMT will have positive influence on the CSR disclosures.

H1c: Education level heterogeneity in TMT will have positive influence on the CSR disclosures.

\section{2) Top Management Team Characteristics and Financial Performance}

As firm are said to be reflections of their top management team, TMT demographic characteristics has a key impact on firm's actions and their outcomes. Another crucial assumption of [6] upper echelons perspective is that the impacts of top corporate players can be examined better based on the characteristics of the entire top management team, rather than based on the values and attributes of each top managers separately [6]. Therefore, top managers play a vital role in influencing the strategic behaviour and performance of the organization through understanding the internal and external environment of the enterprise. Heterogeneity in teams is related to greater creativity and innovation [37]. Age heterogeneity is expected to bring diversity of viewpoints in decision making process as individual group members have different interpretations and viewpoints [29]. In other words, top managers in different age groups play different roles in enhancing business decision-making according to their own social principles, difference in values and perceptions. Gender heterogeneity can impact the firm's financial performance [38]. In [39] they found that the proportion of female executives was significantly correlated with corporate ROE, ROS and ROIC by analyzing data from 500 listed companies in the United States. Top managers with diverse educational level have the higher ability to cope with various complex problems and can maintain a balance between short-term and long-term orientation, facilitating strategic choices which can further improve the firm's performance [40]. In paper [15] they found that TMT with diverse characteristics had a positive effect on airline performance. Therefore, the following hypotheses are proposed:

H2: The TMT heterogeneity will have positive influence on financial performance.

H2a: Age heterogeneity in TMT will have positive influence on the financial performance.

H2b: Gender heterogeneity in TMT will have positive influence on the financial performance.

H2c: Education level heterogeneity in TMT will have positive influence on the financial performance.

3) Corporate Social Responsibility Disclosure and Financial Performance

The quality of CSR disclosure directly impacts the consumers' reputation, their satisfaction and their loyalty towards the enterprises. The volume of corporate social responsibility disclosure will always send a positive message to the community, which not only boosts the performance of the enterprises but they are also well accepted and more recognized which further enhances the overall image of the enterprises. A study by [41] showed a positive relationship between 
a firm's CSR strategies and its performance. It is also considered that corporate social responsibility behavior is one of the effective ways to gain competitive advantage [42]. Most of the studies found a positive relation between CSR disclosure and financial performance [43] [44]. Firms disclosing more CSR activities in both annual reports and websites can act as firm's competitive advantage which can lead to a better financial performance. Therefore, the following hypotheses are proposed:

H3: CSRD is positively associated with financial performance.

\section{4) Mediating Role of Corporate Social Responsibility Disclosure}

TMT heterogeneity affects performance of the corporation by influencing strategic choices. Corporate social responsibility is a unique strategy for enterprises. We believe that it plays an intermediary role in the relationship between managerial cognition and financial performance, that is, heterogeneity of top management team affect the level of corporate social responsibility disclosures which have positive influence on corporate financial performance. For example, top managers pay attention in performing corporate social responsibility behavior to improve the customer support and cohesion, thereby improving market reputation and share, which will have a positive effect on corporate financial performance. Corporate social responsibility plays a pivotal role for enhancing both organizational social performance and its financial performance [42]. Considering this point of view, we believe that CSRD mediates the relationship between TMT heterogeneity and financial performance. Therefore, top management heterogeneity can indirectly improve corporate performance through CSR behaviour. Based on this, the study proposes the following hypothesis:

H4: Corporate social responsibility disclosures mediate the relationship between TMT heterogeneity and financial performance.

\section{Research Methodology}

In this research, the association between TMT heterogeneity, CSRD and financial performance of the top 29 banks registered under Nepal Stock Exchange (NEPSE) from Nepal is studied and analyzed. There are 27 commercial banks and 33 development banks as of year 2017. Among them top 29 banks samples are selected for the years 2012-2017 according to their Market capitalization registered under Nepal Stock Exchange (NEPSE) and data availability related to research in annual reports. The yearly data of the sample period of six years (2012-2017) is used in this study, with the vision of achieving a larger sample. The selected period gives us the opportunity for observing the years of implementation of G4 GRI guidelines by the listed banks in Nepal. GRI is widely used as an underlying guideline for the coding structure of the content analysis of annual reports in both developed and developing countries context. It had provided the appropriate guidelines called Financial Service Sector (FSS), commonly known as GRI-FSS to report on financial sectors. For financial institutions GRI guidelines is major initiatives which tend to focus on supporting the key responsibility of financial sector to disclose CSR information. It also set out 
some applicable principles and indicators that a banking sector can use to measure and report its economic, social and environmental disclosures

(https://www.globalreporting.org/). Collection of data is always a challenge for any research. One of the sources for data collection was the annual reports of the different banks selected for the study. In some cases, I personally visited the banks to gather information for the purpose of data collection for this study, also used other channels like recommendations and relationships to gather some additional information when needed. To generate a standardized dataset, this study only focuses on commercial ("A" class) and development ("B" class) banks from Nepal, which is a developing country. The final samples are selected from top 29 banks among which 26 are commercial banks and 3 are development banks.

\section{Variable Selection and Measurement}

\subsection{Dependent Variables: Financial Performance}

According to Harvard Business Review article, the best way to measure firm financial performance is ROA because ROA explicitly takes into account the assets used to support the structural activities of the organization. Moreover, it determines whether the firm is able to generate an adequate return on these assets rather than simply showing robust returns on sales. Therefore, ROA is selected so as to improve the persuasiveness of the research results. ROA is a measure of firm financial performance, which can show the overall evaluation of the performance of listed corporations. The higher the ratio, the better it is for the investor who looks at the company and is willing to invest in the company. Paper [45] defines the ROA as follows:

$$
\text { ROA }=\text { Net Profit/Total Assets }
$$

\subsection{Independent Variables and Mediating Variable}

The present study considers TMT (age, gender and education heterogeneity) as independent variable and CSRD as mediating variable. These variables and their measurement are explained below in the context of this study.

TMT age was calculated via the biographical information of the top executives who can significantly influence on business decision-making process. TMT Education Level is calculated on a four-point scale (i.e. $0=$ no college degree, $1=$ undergraduate-level, $2=$ master-level, $3=$ doctoral level). Coefficient of variation were calculated (i.e. the standard deviation divided by the mean) for measuring heterogeneity of age and education level [37]. Gender heterogeneity is measured as the proportion of female in TMT.

CSRD: The CSRD is the mediating variable in this study. To assess the extent of CSR disclosure in annual reports, the content analysis technique was applied in stimulating data from the annual report. This technique is selected because it is systematic replicable technique and commonly used method of measuring corporate social responsibility disclosure in annual reports [18]. A dichotomous 
method is applied whereby a company is allotted 1 if an item is disclosed and 0 if it is not disclosed. Thus, in this paper, the disclosing categories of CSR are extracted from GRI G4 guidelines. GRI guidelines is followed because it set out some specific principles and indicators that a bank can use to measure and report its economic, social and environmental disclosures (https://www.globalreporting.org/). A total of thirty-seven items of CSR disclosure information has been collected from the GRI G4 guidelines. Among them, ten items are linked with economic disclosure; seventeen items are linked with social disclosure; and ten items are linked with environmental disclosure. Those disclosure indices are similar to the disclosure disclosed by the prior researcher [7]. The CSR disclosures scores is calculated using the corporate social responsibility disclosure index expressed in a function form as follows:

$$
\mathrm{CSR}=\sum_{j=1} \frac{d_{j}}{n}
$$

where, $d_{j}=1$, if the item is disclosed; and 0 if the item is not disclosed, $n=$ number of items.

\subsection{Control Variable}

The control variables included in the proposed model for this study is bank size, bank age, bank ownership structure, number of branches and year of the published annual reports. The bank size is measured by taking the natural log of total assets. Bank age is computed from the date of establishment until the end of fiscal year. The ownership structure of bank can be measured as state ownership and non-state ownership bank. Thus, if a bank is owned by state, the value of 1 is assigned and if a bank is of non-state ownership, the value of 0 is assigned. Branches of banks are measured by the number of branches of bank in Kathmandu valley (the capital city of Nepal). The year of published annual report is taken as dummies to control for undetected heterogeneity. Table 1 presents the summary of the variables and their measurement.

\section{Results and Discussion}

\subsection{Descriptive Statistics}

Before we determine the descriptive statistics, the normality of the distribution of ROA is tested. To deal with these outliers there are two common methods or techniques which is generally used. First method is called deleting or trimming or removing data and the second method is called winsorizing of the data. In this research the second method winsorizing of the data is applied to deal with outliers. To be confirmed whether the variables (ROA) are normally distributed, the normality test in SPSS is conducted using the Kolmogorov-Smirnov and Shapiro-Wilk test. The results of these two tests show that both are not significant at the level of $1 \%$ and it tells that ROA are significantly normally distributed. The outliers are winsorized by using the mean for ROA which is 0.0159 . To determine whether in the regression model there is an inequality of variance from 
Table 1. Summary of the variables and their measurement.

\begin{tabular}{|c|c|c|}
\hline Variable & Variable Name & Measurement \\
\hline \multirow[t]{2}{*}{ Dependent variable } & ROA & Net Profit/Total Assets \\
\hline & Hage & $\begin{array}{l}\text { The biographical information of the top } \\
\text { managers }\end{array}$ \\
\hline \multirow[t]{2}{*}{ Independent variable } & Hgender & Proportion of female members in TMT \\
\hline & Heducation & $\begin{array}{c}\text { No college degree }=0 \text {, Undergraduate-level }= \\
1, \text { Master-level }=2 \text {, Doctoral level }=3\end{array}$ \\
\hline \multirow[t]{3}{*}{ Mediating variable } & $\begin{array}{c}\text { Corporate Social Responsibility } \\
\text { Disclosure (CSRD) }\end{array}$ & $\begin{array}{c}\text { Scoring of CSR disclosure index } \\
\text { (Economic + social + Environment })\end{array}$ \\
\hline & Bank Size & Natural logarithm of total assets \\
\hline & Bank Age & No. of year in business \\
\hline \multirow[t]{3}{*}{ Control variable } & Ownership Structure & $\begin{array}{c}\text { State ownership = } 1 \text { and Non-state ownership } \\
\text { bank }=0\end{array}$ \\
\hline & Branches & No. of branches of company \\
\hline & Year & Year of published annual report \\
\hline
\end{tabular}

one residual observation to another it is crucial to test the heteroscedasticity. If the observed residual variant from one observation remains fixed or homoscedasticity then it is a good regression model. This study did not violate the assumptions of heteroscedasticity of variance assessed from scatter plot.

The statistical software of Stata (SPSS version 22) was used to analyze the relationship between variables of this study. Table 2 provides descriptive statistics of the variables in the study. All the variables were collected from the annual reports and statement of financial position of the sample banks. The mean of the dependent variable ROA is 0.0159 which explains that majority of the listed banks have a ROA of $1.59 \%$. CSRD has a mean of 23.28 which further suggested that $23.28 \%$ of the sample banks over the selected time period disclosed their CSR activities. The Hage ranges from 0 to 0.71 whereas the average Hage is 0.1247. Proportion of female members in the TMT is used as in indicator of gender heterogeneity which ranges from $0 \%$ to $33 \%$ and the average value of 0.0446 indicates that $4.46 \%$ of the executives in the TMT of listed banks listed in Nepal Stock Exchange are females. The mean value and standard deviation of education level heterogeneity are 0.3581 and 0.08789 respectively. The descriptive statistics of the financial indicators are given in Table 2.

\subsection{Correlation Analysis}

Table 3 presents the coefficient correlation between the dependent and the independent variables, and determines whether or not multi-collinearity exists as a result of the correlation between variables. The correlation matrix shown in $\mathrm{Ta}$ ble 3 provides an insight into which of the independent variables are related to the dependent variables involved in this study. The correlation values of variable in the table are significant at the levels $1 \%$ and $5 \%$. The correlation matrix shows the relationship between all pairs of explanatory variables used in this model. It 
Table 2. Descriptive statistics of variable.

\begin{tabular}{cccccc}
\hline Variable & $\mathrm{N}$ & Minimum & Maximum & Mean & Std. Deviation \\
\hline ROA & 174 & 0.00 & 0.04 & 0.0159 & 0.00691 \\
CSRD & 174 & 18.00 & 32.00 & 23.2816 & 3.08755 \\
Hage & 174 & 0.00 & 0.71 & 0.1247 & 0.06141 \\
Hgender & 174 & 0.00 & 0.33 & 0.0446 & 0.08616 \\
Heducation & 174 & 0.17 & 0.54 & 0.3581 & 0.08789 \\
Bank Size & 174 & 9.42 & 11.18 & 10.5794 & 0.35097 \\
Bank Age & 174 & 0.02 & 0.8 & 0.14983 & 0.154828 \\
Ownership & 174 & 0 & 1 & 0.07 & 0.254 \\
Branches & 174 & 0.05 & 0.32 & 0.1619 & 0.07241 \\
Year & 174 & 0 & 5 & 2.50 & 1.713 \\
\hline
\end{tabular}

Table 3. The correlation matrix between variables.

\begin{tabular}{|c|c|c|c|c|c|c|c|c|c|c|}
\hline Variable & $\mathrm{ROA}$ & CSRD & Hage & Hgender & Heduation & Bank Size & Bank Age & Ownership & Branches & Year \\
\hline ROA & 1 & & & & & & & & & \\
\hline CSRD & $0.454^{* *}$ & 1 & & & & & & & & \\
\hline Hage & $0.235^{\star *}$ & $0.258^{\star *}$ & 1 & & & & & & & \\
\hline Hgender & $0.160^{\star}$ & -0.019 & -0.096 & 1 & & & & & & \\
\hline Heduation & $0.181^{\star}$ & $0.230^{* *}$ & 0.095 & 0.033 & 1 & & & & & \\
\hline Bank Size & $0.193^{\star}$ & $0.361^{* *}$ & $0.158^{*}$ & -0.057 & $0.241^{* *}$ & 1 & & & & \\
\hline Bank Age & $0.284^{* *}$ & $0.425^{* *}$ & $0.319^{* *}$ & 0.060 & -0.020 & $0.493^{* *}$ & 1 & & & \\
\hline Ownership & $0.161^{*}$ & $0.248^{* *}$ & $0.260^{* *}$ & $0.215^{* *}$ & -0.046 & $0.285^{* *}$ & $0.829^{* *}$ & 1 & & \\
\hline Branches & 0.010 & 0.105 & 0.104 & -0.076 & $0.197^{\star \star}$ & $0.462^{\star *}$ & 0.125 & -0.017 & 1 & \\
\hline Year & $0.245^{\star *}$ & $0.182^{*}$ & 0.037 & -0.026 & 0.094 & $0.487^{* *}$ & 0.111 & 0.000 & $0.278^{\star *}$ & 1 \\
\hline
\end{tabular}

${ }^{* *}$ Correlation is significant at the 0.01 level (2-tailed). ${ }^{*}$ Correlation is significant at the 0.05 level (2-tailed).

shows that all the explanatory variables have a positive and significant correlation with the dependent variable (ROA) with the exception of branches, which show a positive but insignificant correlation. The positive correlations imply that as the disclosure of CSR, age, gender and education heterogeneity on TMT, bank size, bank age, ownership structure and year increases, the financial performance (ROA) of listed banks also increases. The values of all variable used on the diagonal are all 1.0000 which shows that each variable is perfectly correlated with itself. In the correlation analysis of variables, we can determine that the initial problem of collinearity between variables generally take place if the correlation coefficient is above 0.9 [46]. Table 3 shows the correlation coefficient did not exceed 0.9 which indicates that there is no multiple collinearity problem.

Table 4 presents that TV ranges from 0.225 to 0.891 which suggests non multi-collinearity feature. Multi-collinearity feature exists when the tolerance value 
Table 4. Multicollinearity test.

\begin{tabular}{ccc}
\hline \multirow{2}{*}{ Variable } & \multicolumn{2}{c}{ Collinearity Statistics } \\
\cline { 2 - 3 } & Tolerance & VIF \\
\hline Hage & 0.867 & 1.153 \\
Hgender & 0.887 & 1.127 \\
Heduation & 0.891 & 1.112 \\
Bank Size & 0.442 & 2.263 \\
Bank Age & 0.225 & 4.451 \\
Ownership & 0.265 & 3.767 \\
Branches & 0.752 & 1.329 \\
Year & 0.734 & 1.363 \\
\hline
\end{tabular}

Dependent variable: ROA.

is less than 0.1 and VIF value over 10. The VIF, which is simply the reciprocal of TV, range from 1.112 to 4.451 . Thus, the VIF and tolerance test indicates the absence of multi-collinearity problem among the independent variables in the study. Table 4 represents the results of TV and VIF for the TMT heterogeneity components.

\subsection{Multivariate Regression Analysis and Hypothesis Testing}

Through multivariate regression analysis, we study and analyze the relationship of TMT heterogeneity, and CSRD and financial performance. The results of the multivariate regression analysis are used for the purpose of analysis on whether to accept or reject the proposed hypotheses. For the hypothesis to be accepted, the proposed variables must have a significance level of up to $10 \%$. This is to protect explanatory variables already admitted in the equation having significance level higher than $5 \%$ but not over $10 \%$.

As shown in Table 5, Age heterogeneity $(r=0.139, \mathrm{p}<0.050)$ is positively related to corporate social responsibility disclosure, which supports H1a. On the other hand, gender heterogeneity in TMT was found to be insignificant and the findings does not support hypothesis $1 \mathrm{~b}$. Education level heterogeneity $(\mathrm{r}=$ $0.218, \mathrm{p}<0.010)$ is positively related to CSR disclosures, which confirmed H1c. Age heterogeneity $(r=0.174, p<0.050)$, gender heterogeneity $(r=0.204, p<$ $0.010)$, and education level $(r=0.178, p<0.050)$ in TMT was also positively related to financial performance, which provided support for $\mathrm{H} 2 \mathrm{a}, \mathrm{H} 2 \mathrm{~b}$ and $\mathrm{H} 2 \mathrm{c}$. With regard to the third hypothesis (H3), corporate social responsibility disclosure $(r=0.381, p<0.001)$ was positively related to financial performance, which supports H3. The method of [47] was proposed for testing the intermediary variables of four regression equations and determined the mediating effect of corporate social responsibility disclosures. Corporate social responsibility disclosures was positively related to financial performance, but the impact of TMT age heterogeneity was weakened significantly $(r=0.135, \mathrm{P}<0.100)$ and the impact 
Table 5. Results of regression analysis.

\begin{tabular}{|c|c|c|c|c|c|c|c|c|c|}
\hline \multirow{2}{*}{ Variable } & \multicolumn{5}{|c|}{ Corporate Social Responsibility Disclosure } & \multicolumn{4}{|c|}{ Financial performance (ROA) } \\
\hline & Model 1 & Model 2 & Model 3 & Model 4 & Model 5 & Model 6 & Model 7 & Model 8 & Model 9 \\
\hline Constant & 7.794 & 6.596 & 7.709 & 11.634 & 10.278 & 0.024 & 0.025 & 0.017 & 0.017 \\
\hline Bank Size & 0.154 & 0.158 & 0.152 & 0.080 & 0.090 & -0.057 & -0.099 & -0.115 & -0.128 \\
\hline Bank Age & $0.584^{* * *}$ & $0.538^{* * *}$ & $0.589^{\star * *}$ & $0.633^{* * *}$ & $0.596^{* * *}$ & $0.485^{* * *}$ & $+0.539^{\star * *}$ & $0.262+$ & $0.344^{*}$ \\
\hline Ownership & $-0.281^{*}$ & $-0.281^{*}$ & $-0.287^{*}$ & $-0.291^{*}$ & $-0.298^{*}$ & $-0.226+$ & $-0.341^{\star *}$ & -0.119 & $-0.243+$ \\
\hline Branches & -0.060 & -0.071 & -0.060 & -0.080 & -0.089 & -0.096 & -0.125 & -0.074 & -0.096 \\
\hline Year & YES & YES & YES & YES & YES & YES & YES & YES & YES \\
\hline Hage & & $0.139^{\star}$ & & & $0.119+$ & & $0.174^{\star}$ & & $0.135+$ \\
\hline HGender & & & 0.013 & & 0.015 & & $0.204^{* *}$ & & $0.199^{* *}$ \\
\hline Heducation & & & & $0.218^{\star *}$ & $0.205^{\star *}$ & & $0.178^{*}$ & & 0.111 \\
\hline CSRD & & & & & & & & $0.381^{* * *}$ & $0.327^{* * x}$ \\
\hline $\mathrm{R} 2$ & 0.238 & 0.256 & 0.238 & 0.281 & 0.294 & 0.150 & 0.245 & 0.260 & 0.321 \\
\hline $\mathrm{F}$ & $10.509^{* * *}$ & $\star 9 . .556^{* * *}$ & $8.713^{\star * *}$ & $10.897^{* * *}$ & $* 8.577^{* * *}$ & $5.920^{* * *}$ & $6.705^{* * *}$ & $9.798^{\star * *}$ & $8.610^{* * *}$ \\
\hline
\end{tabular}

of TMT education level heterogeneity on financial performance became insignificant $(\mathrm{r}=0.111, \mathrm{p}>0.1)$. This provided support for $\mathrm{H} 4$.

\section{Conclusion, Implication and Recommendations for Future Research}

Based on upper echelons and legitimacy theories background, this research explored the relationship between TMT heterogeneity, CSRD and financial performance. To test the hypothesis proposed in this study, a sample of top 29 banks listed in Nepal Stock Exchanges (NEPSE) in Nepal was observed from the year 2012 to 2017. The findings of the study based on multivariate regression analysis showed that heterogeneity of age and education level in TMT has a positive link towards corporate social responsibility disclosure, which indicates that executives composed of diverse characteristics, skilled profile and perspectives facilitates group creativity, innovation and can make better decisions which would account to achieve better outcome [29]. This study also observed that proportion of female members in the TMT has an insignificant impact on corporate social disclosure (CSRD). Nepal female's participation in top management team is not like the other developing countries, which also reflects the dominance of male members in top management team for the selected banks. Female members mostly act as latent members of the top management team. Empirical findings support the literature related to the accepted hypothesis, though theoretical link between TMT heterogeneity, corporate social responsibility disclosure and financial performance is still weak, especially in developing country context. 


\section{Implications}

This study reveals the relationship between TMT heterogeneity, CSRD and financial performance literature. This study supports the literature from CSR disclosure perspective especially in developing country's context. Firstly, as the study focuses on the banking sector of Nepal, one of the major contributor for sustainable development, this paper examines corporate social responsibility (CSR) disclosures where CSR is in an infant stage of development in Nepal and examines the present status of CSR disclosure in Nepalese banking sector and the factors that influence CSR disclosure and performance in Nepalese banks. Secondly, this study finds the relationship between heterogeneity in company's top managers and CSR disclosures, attention is paid to the human aspect of banks, i.e. business activities and strategic decision are driven by top managers. Thirdly, in this transitional period in Nepal, organization must adjust and reallocate the intention to disclose CSR activities information to standardize and upgrade CSR in a timely manner in order to improve financial performance effectively. From practical implications perspective, findings reveal that heterogeneity in age and education level have significant influences on the extent of CSR disclosures which are likely to predict increase in performance of banks in Nepal. These findings not only contribute to the upper echelon literature but also to growing literature on CSR perspective by supporting the importance of CSR disclosures in the financial sector from a developing country perspective. Therefore, this study is first to provide them a clear understanding of this complex and growing concept so that efficient standards can be put in and provides a new perspective to reveal the "black box" relationship between organizational leaders who exhibit CSR disclosures and firm financial performance.

\section{Limitations and Future Research}

The findings of this study are not free from few limitations. There are some limitations to this study as well. The samples selected in this study are limited to commercial banks ("A" class) and development banks ("B" class) of Nepal. The results may not be valid and effective to other class of banks in Nepal such as cooperative banks and finance companies [7]. Furthermore, some development banks were excluded from the study due to unavailability of annual reports. Thus, the findings from this study cannot be generalized to the overall Nepalese banking sector. Future research need to study the impact of TMT psychological characteristics on extent of CSR disclosure may enrich the CSR literature. This research can be further explored from CEO ideologies and profiles perspective may help to get more understanding of CSR related studies and may expand and explore the body of research on banking sector of Nepal.

\section{Conflicts of Interest}

The author declares no conflicts of interest regarding the publication of this paper. 


\section{References}

[1] Burton, B. and Goldsby, M. (2009) Corporate Social Responsibility Orientation, Goals and Behaviour: A Study of Small Business Owners. Business \& Society, 48, 88-104. https://doi.org/10.1177/0007650307305367

[2] Sweeney, L. (2009) A Study of Current Practice of Corporate Social Responsibility (CSR) and an Examination of the Relationship between CSR and Financial Performance Using Structural Equation Modelling (SEM). Dublin Institute of Technology.

[3] Welzel, C. (2006) Corporate Social Responsibility in Nepal: A Chance for Peace and Prosperity? Report Based on Mission to Nepal.

[4] Gray, R., Javad, M., Power, D.M. and Sinclair, C. (2001) Social and Environmental Disclosure and Corporate Characteristics: A Research Note and Extension. Journal of Business Finance \& Accounting, 28, 327-356. https://doi.org/10.1111/1468-5957.00376

[5] Hackston, D. and Milne, M.J. (1996) Some Determinant of Social and Environmental Disclosures in New Zealand Companies. Accounting, Auditing \& Accountability Journal, 9, 77-108. https://doi.org/10.1108/09513579610109987

[6] Hambrick, D.C. and Mason, P.A. (1984) Upper Echelons: The Organization as a Reflection of Its Top Managers. Academy of Management Review, 9, 193-206. https://doi.org/10.5465/amr.1984.4277628

[7] Bidari, G. (2016) Factors Affecting CSR Disclosure in Nepalese Banks: A Global Reporting Initiative Perspective. http://ro.ecu.edu.au/theses/1803

[8] Simmons, J.M. (2016) An Examination of Determinants of Corporate Social Responsibility Disclosure Strategies. In: Plangger, K., Ed., Thriving in a New World Economy, Springer, Berlin, 289-292. https://doi.org/10.1007/978-3-319-24148-7_86

[9] Roberts, R.W. (1992) Determinants of Corporate Social Responsibility Disclosure: An Application of Stakeholder Theory. Accounting, Organizations and Society, 17, 595-612. https://doi.org/10.1016/0361-3682(92)90015-K

[10] Hambrick, H. (2007) Upper Echelons Theory: An Update. Academy of Management Review, 32, 334-343. https://doi.org/10.5465/amr.2007.24345254

[11] Finkelstein, S. and Hambrick, D.C. (1996) Strategic Leadership: Top Executives and Their Effects on Organizations. West, Minneapolis.

[12] Lee, S.W., Kim, C., Moon, J. and Yoon, H. (2017) Impact of Airline Top Management Teams on Corporate Social Responsibility. Tourism Analysis, 22, 19-29. https://doi.org/10.3727/108354217X14828625279591

[13] Baele, A. and Van, L.O. (2012) The CEO's Perception on CSR: A Determinant of CSR Reporting. Universiteit Gent.

[14] Knight, D., Pearce, C.L., Smith, K.G., Olian, J.D., Sims, H.P., Smith, K.A. and Flood, P. (1999) Top Mana Gement Team Diversity, Group Process, and Strategic Consensus. Strategic Management Journal, 20, 445-465. https://doi.org/10.1002/(SICI)1097-0266(199905)20:5<445::AID-SMJ27>3.0.CO;2-V

[15] Hambrick, D.C., Cho, T.S. and Chen, M.J. (1996) The Influence of Top Management Team Heterogeneity on Firm's Competitive Moves. Administrative Science Quarterly, 41, 659-684. https://doi.org/10.2307/2393871

[16] Bear, S., Rahman, N. and Post, C. (2010) The Impact of Board Diversity and Gender Composition on Corporate Social Responsibility and Firm Reputation. Journal of Business Ethics, 97, 207-221. https://doi.org/10.1007/s10551-010-0505-2 
[17] Tsoutsoura, M. (2004) Corporate Social Responsibility and Financial Performance. University of California Berkle, California, USA.

[18] Isa, A.M. and Muhammad, S. (2015) The Impact of Board Characteristics on Corporate Social Responsibility Disclosure: Evidence from Nigerian Food Product Firms. International Journal of Management Science and Business Administration, 1, 34-45.

[19] Ali, M.A. and Attan, R.H. (2013) The Relationship between Corporate Governance and Corporate Social Responsibility Disclosure: A Case of Malaysian Sustainability Companies and Global Sustainability Companies. South East Asia Journal of Contemporary Business, Economics and Law, 1, 39-48.

[20] Brammer, S. and Millington, A. (2006) Firm Size, Organizational Visibility and Corporate Philanthropy: An Empirical Analysis. Business Ethics, 15, 6-18. https://doi.org/10.1111/j.1467-8608.2006.00424.x

[21] Sturdivant, F.D. and Ginter, J.L. (1977) Corporate Social Responsiveness. California Management Review, 19, 30-39. https://doi.org/10.2307/41164709

[22] Naranjo-Gil, D., Hartmann, F.G.H. and Maas, V.S. (2008) Top Management Team Heterogeneity, Strategic Change and Operational Performance. British Journal of Management, 19, 222-234. https://doi.org/10.1111/j.1467-8551.2007.00545.x

[23] Slater, D.J. and Dixon-Fowler, H.R. (2009) CEO International Assignment Experience and Corporate Social Performance. Journal of Business Ethics, 89, 473-489. https://doi.org/10.1007/s10551-008-0011-y

[24] Eisenhardt, K.M. and Bougeois, L.J. (1988) Politics of Strategic Decision Making in High-Velocity Environments: Toward a Midrange Theory. Academy of Management Journal, 31, 737-770.

[25] Rehman, U.R., Ikram, A. and Malik, F. (2017) Impact of Board Characteristics on Corporate Social Responsibility Disclosure. Journal of Applied Business Research, 33, 801-810. https://doi.org/10.19030/jabr.v33i4.10001

[26] Cormier, D. and Magnan, M. (2015) The Economic Relevance of Environmental Disclosure and Its Impact on Corporate Legitimacy: An Empirical Investigation. Business Strategy and the Environment, 24, 431-450. https://doi.org/10.1002/bse.1829

[27] Zhu, Y. (2013) The Impact of Top Management Team Process on Corporate Social Responsibility and Firm Performance. School of Management, Macau University of Science and Technology, 7, 268-288.

[28] Murray, A. and Gray, R. (2006) Do Financial Markets Care about Social and Environmental Disclosure? Further Evidence and Exploration from the UK. Account Audit Account Journal, 19, 228-255. https://doi.org/10.1108/09513570610656105

[29] Wiersema, M.F. and Bantel, K.A. (1992) Top Management Team Demography and Corporate Strategic Change. Academy of Management Journal, 35, 91-121.

[30] Di Giuli, A. and Kostovetsky, L. (2014) Are Red or Blue Companies More Likely to Go Green? Politics and Corporate Social Responsibility. Journal of Financial Economics, 111, 158-180. https://doi.org/10.1016/j.jfineco.2013.10.002

[31] Greening, D. and Johnson, R. (1997) Managing Industrial and Environmental Crises: The Role of Heterogeneous Top Management Teams. Business \& Society, 36, 334-362. https://doi.org/10.1177/000765039703600402

[32] Kahreh, M.S., Babania, A., Tive, M. and Mirmehdi, S.M. (2014) An Examination to Effects of Gender Differences on the Corporate Social Responsibility (CSR) Proce- 
dia: Social and Behavioral Sciences, 109, 664-668. https://doi.org/10.1016/j.sbspro.2013.12.525

[33] Ibrahim, N.A. and Angelidis, J.P. (1994) Effect of Board Members Gender on Corporate Social Responsiveness Orientation. Journal of Applied Business Research, 10, 35. https://doi.org/10.19030/jabr.v10i1.5961

[34] Zhang, L. (2012) Board Demographic Diversity, Independence, and Corporate Social Performance. Corporate Governance, 12, 686-700. https://doi.org/10.1108/14720701211275604

[35] Carter, D.A., Simkins, B.J. and Simpson, W.G. (2003) Corporate Governance, Board Diversity, and Firm Value. Financial Review, 38, 33-53. https://doi.org/10.1111/1540-6288.00034

[36] Cacioppe, R., Forster, N. and Fox, M. (2008) A Survey of Managers Perceptions of Corporate Ethics and Social Responsibility and Actions that May Affect Companies Success. Journal of Business Ethics, 82, 681-700. https://doi.org/10.1007/s10551-007-9586-y

[37] Goll, I., Sambharya, R.B. and Tucci, A.L. (2001) Top Management Team Composition, Corporate Ideology, and Firm Performance. The Management International Review, 41, 109-129.

[38] Dawar, G. and Singh, S. (2016) Corporate Social Responsibility and Gender Diversity: A Literature Review. Journal of IMS Group, 13, 61-71.

[39] Catalyst (2007) Catalyst Census of Women Board Directors of the Fortune 1000. Catalyst, New York.

[40] Goll, I., Johnson, N.B. and Rasheed, A.A. (2008) Top Management Team Demographic Characteristics, Business Strategy and Firm Performance in the US Airline Industry: The Role of Managerial Discretion. Organization Science, 46, 201-222.

[41] Fang, S., Huang, C. and Huang, S. (2010) Corporate Social Responsibility Strategies, Dynamic Capability and Organizational Performance: Cases of Top Taiwan-Selected Benchmark Enterprises. African Journal of Business Management, 4, 120-132.

[42] Porter, M.E. and Kramer, M.R. (2002) The Competitive Advantage of Corporate Philanthropy. Harvard Business Review, 80, 56-69.

[43] Qiu, Y., Shaukat, A. and Tharyan, R. (2016) Environmental and Social Disclosures: Link with Corporate Financial Performance. The British Accounting Review, 48, 102-116. https://doi.org/10.1016/j.bar.2014.10.007

[44] Platonova, E., Asutay, M., Dixon, R. and Mohammad, S. (2016) The Impact of Corporate Social Responsibility Disclosure on Financial Performance: Evidence from the GCC Islamic Banking Sector. Journal of Business Ethics, 151, 451-471. https://doi.org/10.1007/s10551-016-3229-0

[45] Bhuyan, M., Lodh, S.C. and Perera, N. (2017) The Effects of Corporate Social Disclosure on Firm Performance: Empirical Evidence from Bangladesh. Accounting and Finance Association of Australia and New Zealand Conference, Beijing 17-18 June 2017, 1-36.

[46] Tabachnick, B.G. and Fidell, L.S. (2007) Using Multivariate Statistics. Harper Collins, New York.

[47] Byrne, B.M. (2001) Structural Equation Modeling with AMOS: Basic Concepts, Applications, and Programming. Lawrence Erlbaum Associates Inc., New York. 